\title{
VERIFIKASI CITRA TANDA TANGAN BERBASIS PERCEPTRON
}

\author{
Latifah Listyalina $^{1}$, Irawadi Buyung ${ }^{2}$ \\ Jurusan Teknik Elektro, Fakultas Sains \& Teknologi Universitas Respati Yogyakarta ${ }^{1,2)}$ \\ Jl. Laksda Adisucipto Km 6,3 Depok, Sleman, Yogyakarta, Indonesia 55281 \\ E-mail : listyalina@gmail.com ${ }^{1}$, buyungirawadi@gmail.com²
}

\begin{abstract}
A signature has become an important human attribute, which can represent personal information. Human signatures are widely used to authorize documents, both paper-based as well as electronicbased ones. However, such authorization still poses various privacy issues, such as signature duplication and forgeries. These may not be easy to be addressed, particularly when involving many documents. Hence, advanced procedures are required to verify the signature authenticity. In this paper, we propose a new method for automatic signature verification based on the digitalized signature images. The method comprises successive image processing techniques, such as cropping, resizing, gray-scaling and binarization. The binary images as the results of binarization serve as the features of the signatures and are used to train a single layer Perceptron neural network. The experiment in this paper uses 42 digitalized signatures images, collected from two subjects. The obtained images are divided into the training and testing sets, in which the training and testing sets comprise 14 and 28 images, respectively. In the experiment, the proposed method produces the average training and testing accuracies of $100 \%$ and $98.85 \%$, respectively. These indicate that the proposed method is reliable for practical applications.
\end{abstract}

Keywords : Binary, Bio-Metrics, Images, Perceptron, Signatures, Verification.

\section{PENDAHULUAN}

Tanda tangan adalah hasil dari proses menulis seseorang yang bersifat khusus sebagai substansi simbolik. Tanda tangan merupakan bentuk yang paling banyak digunakan untuk verifikasi seseorang. Contoh - contoh tanda tangan setiap orang umumnya identik namun tidak sama (Abbas, R. 1994). Selain untuk verifikasi, tanda tangan juga dapat digunakan sebagai bukti verifikasi identitas seseorang. Verifikasi tanda tangan kebanyakan dilakukan dengan cara manual yaitu dengan membandingkan secara langsung dengan menggunakan mata manusia sendiri, yang mana mempunyai banyak kelemahan, terutama jika dilakukan dalam jumlah tanda tangan yang banyak. Salah satu kelemahannya adalah tingkat ketelitian dan ketepatan hasil verifikasi yang didapatkan seringkali kurang memuaskan. Oleh karena itu, diperlukan sebuah sistem yang mampu menganalisa karakteristik pola tanda tangan sehingga mempermudah dalam memverifikasi tanda tangan seseorang (Andrizal, dkk. 2014).
Sesuai dengan masalah yang telah diuraikan sebelumnya, pada penelitian ini akan dirancang sebuah metode untuk melakukan verifikasi biometrik secara otomatis, khususnya pada citra tanda tangan. Metode ini menggunakan Jaringan Saraf Tiruan Perceptron untuk melakukan pengenalan pada setiap fitur citra tanda tangan. Sasaran dari digunakannya metode ini adalah untuk memperoleh akurasi yang tinggi dengan beban komputasi yang ringan dalam memperoleh hasil verifikasi citra tanda tangan.

\section{TINJAUAN PUSTAKA}

\subsection{Biometrik Tanda Tangan}

Biometrika atau biometrics berasal dari kata bio dan metrics. Bio berarti sesuatu yang hidup dan metrics berarti mengukur. Biometrika berarti mengukur karakteristik pembeda (distinguishing traits) pada badan atau perilaku seseorang. Hasil pengukuran ini digunakan untuk melakukan pengenalan secara otomatis terhadap identitas orang tersebut, dengan membandingkannya dengan 
karakteristik yang sebelumnya telah disimpan pada suatu basis data (Putra, D. 2010).

Biometrik mencakup karakteristik fisiologis dan karakteristik perilaku. Karakteristik fisiologis adalah ciri fisik yang relatif stabil seperti sidik jari, siluet tangan, ciri khas wajah, pola iris, atau retina mata. Sedangkan karakteristik perilaku, seperti tanda tangan, pola ucapan, atau ritme mengetik, yang selain memiliki basis fisiologis yang relatif stabil, juga dipengaruhi kondisi psikologis yang mudah berubah (Hidayatno, dkk. 2008).

\subsection{Pengolahan Citra}

Citra merupakan suatu fungsi dua dimensi, $f(x, y)$, dimana harga dan merupakan koordinat spasial dan amplitudo $f$ disetiap pasangan koordinat $(x, y)$ disebut intensitas atau gray level dari suatu citra di koordinat $(x, y)$ tersebut. (Gonzales, dkk. 2008). Ukuran citra digital dinyatakan dalam titik atau piksel (pixel : picture element) dan dapat pula dinyatakan dalam satuan panjang, misalnya dalam mm atau inci (inch).

Secara visualisasi, dimensi ukuran piksel dinyatakan sebagai lebar $\times$ tinggi. Citra dijital dinyatakan dengan matriks berukuran $\mathrm{N} \times \mathrm{M}(\mathrm{N}$ menyatakan baris atau tinggi, sedangkan $\mathrm{M}$ menyatakan kolom atau lebar) seperti yang diperlihatkan pada gambar 1 (Listyalina, Latifah. 2017).

\subsection{Binerisasi Citra}

Proses binerisasi citra akan menghasilkan citra biner, yaitu citra yang memiliki dua nilai tingkat keabuan (hitam dan putih). Secara umum proses binerisasi citra warna atau citra keabuan untuk menghasilkan citra biner adalah sebagai berikut (Putra, D. 2010) :

$g(x, y)=\left\{\begin{array}{l}1, f(x, y) \geq T \\ 0, f(x, y)<T\end{array}\right.$

Dengan $g(x, y)$ adalah citra biner dari hasil pengambangan citra warna atau citra grayscale $f(x, y)$, dan menyatakan nilai ambang (threshold). Nilai memegang peranan yang sangat penting dalam proses binerisasi. Kualitas citra biner sangat tergantung pada nilai yang digunakan (Putra, D. 2010).

\subsection{Jaringan Saraf Tiruan Perceptron}

Jaringan Saraf Tiruan adalah sistem pemroses informasi yang memiliki karakteristik mirip dengan jaringan saraf biologi. Jaringan saraf tiruan merupakan sistem adaptif yang dapat berubah strukturnya untuk memecahkan masalah berdasarkan informasi yang mengalir melalui jaringan tersebut. Secara sederhana, jaringan saraf tiruan adalah sebuah alat pemodelan data statistik non-linier (Kusumadewi. 2004).

$$
f(x, y)=\left[\begin{array}{cccc}
f(0,0) & f(0,1) & \ldots & f(0, M-1) \\
f(1,0) & f(0,0) & \ldots & f(1, M-1) \\
: & : & : & : \\
f(N-1,0) & f(N-1,1) & \ldots & f(N-1, M-1)
\end{array}\right]
$$

Gambar 1. Matriks Citra Digital $\mathrm{N} \times \mathrm{M}$.

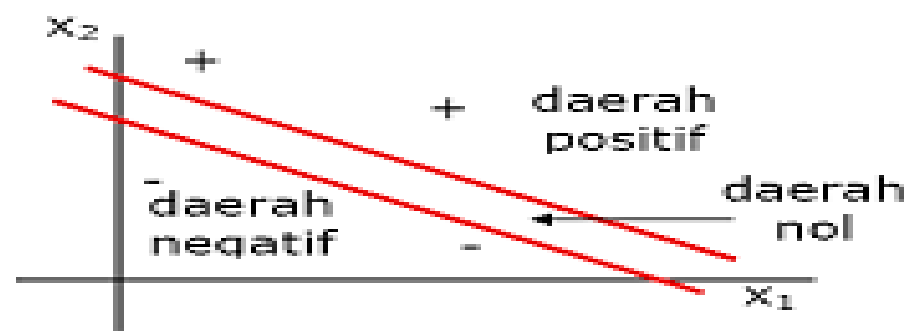

Gambar 2. Pembatasan Linier Pada Jaringan Perceptron. 
Perceptron termasuk salah satu bentuk jaringan saraf tiruan yang sederhana. Perceptron biasanya digunakan untuk mengklasifikasikana suatu tipe pola tertentu yang sering dikenal dengan pemisahan secara linier. Pada dasarnya, perceptron pada jaringan saraf tiruan dengan suatu lapisan memiliki bobot yang dapat diatur.

Alogaritma yang digunakan oleh aturan Perceptron ini mengatur parameter parameter bebasnya melalui proses pembelajaran. Fungsi aktivasi dibuat sedemikian rupa sehingga terjadi pembatasan antara daerah positif dan daerah negatif seperti ditunjukkan oleh gambar 2 (Kusumadewi. 2004).

Pembatasan daerah tersebut dijelaskan oleh garis berwarna merah dimana daerah positif (kelas pertama) terletak di atas garis pembatas dan daerah negatif (kelas kedua) terletak dibawah garis pembatas. Dari gambar 2 tersebut, dapat dilihat bahwa perceptron dapat membagi dua kelas yang berbeda.

\section{METODE PENELITIAN}

Penelitian ini dilaksanakan secara bertahap. Adapun tahapan - tahapan penelitian ditampilkan pada gambar 3 dan dijelaskan sebagai berikut.

\section{A. Tahap 1. Studi Pustaka}

Studi pustaka dilakukan dengan mencari informasi dari buku dan penelitian penelitian terdahulu sebagai upaya meningkatkan kualitas penelitian sebelumnya. Studi pustaka telah dilakukan dengan membandingkan tiga penelitian terlebih dahulu dimana penelitian penelitian tersebut merupakan latar belakang dan acuan dilaksanakannya penelitian ini. Penelitian pertama telah dilakukan oleh Musyaffa, F.A pada tahun 2009 menggunakan metode pengenalan tanda tangan secara offline dengan algoritma klasifikasi Voting Feature Interval 5.

Sebelum dilakukan klasifikasi pada citra tanda tangan yang berdimensi $40 \times 60$ piksel, dilakukan praproses untuk mereduksi ukuran citra. Hasil yang diperoleh dari penelitian ini ialah nilai akurasi lebih dari 90\% untuk level dekomposisi 1 - 3, dan dimensi fitur sekitar 1,5\% dari seluruh fitur. Penelitian ini memiliki tahap - tahap yang panjang, sehingga menyebabkan kompleksitas yang tinggi. Dengan adanya penelitian yang diajukan ini, diharapkan beban komputasi pada proses verifikasi tanda tangan dapat menurun.

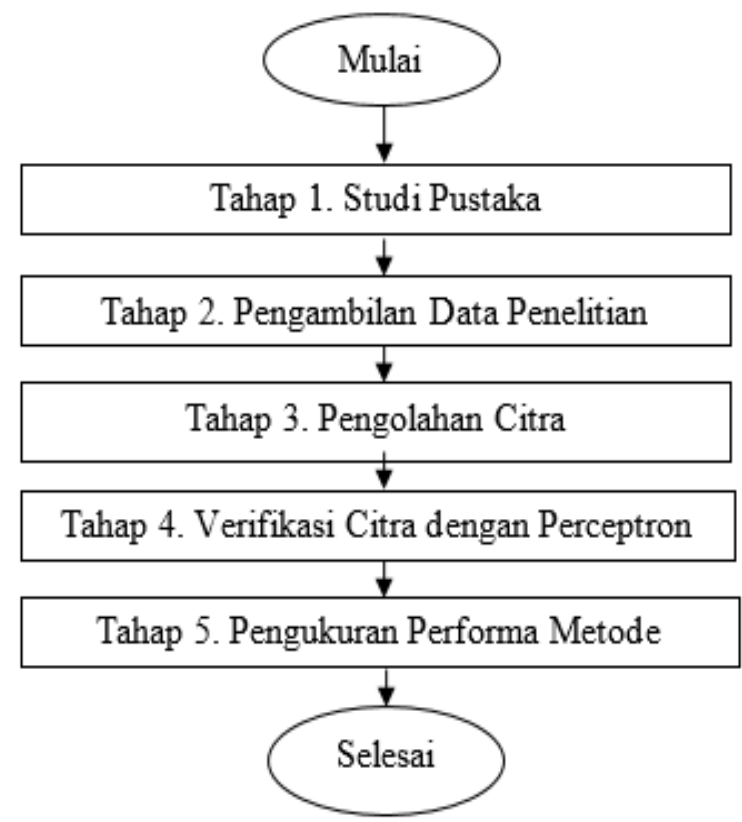

Gambar 3. Tahapan Penelitian. 
Penelitian terkait kedua telah dilakukan oleh Putra pada tahun 2013 dengan menggunakan tiga tahap, yaitu praproses, ekstraksi fitur, dan proses klasifikasi. Pada tahap pertama dan kedua, citra diolah sedemikian rupa sehingga menghasilkan fitur yang unik bagi setiap citra dan digunakan sebagai masukan pada proses klasifikasi serta verifikasi untuk menantukan identitas dari setiap gambar tanda tangan pada data uji.

Proses klasifikasi dan verifikasi dilakukan dengan menggunakan Probabilistic Neural Network. Data yang digunakan adalah 200 buah citra tanda tangan berasal dari 10 responden yang telah di digitalisasi. Citra - citra tersebut terdiri dari 100 citra dengan tanda tangan asli dan 100 citra dengan tanda tangan palsu. Akurasi percobaan pada data tahap pengujian mencapai 91,25\%. Meskipun hasil akurasi tersebut cukup tinggi, diharapkan penelitian yang diajukan mampu menghasilkan performa yang lebih tinggi.

Penelitian acuan terakhir telah dilakukan oleh Widiastuti dengan menerapkan jaringan saraf tiruan (JST) dalam pengenalan pola tanda tangan. Penelitian ini bertujuan membangun sistem yang mampu menganalisis karakteristik tanda tangan sehingga mempermudah proses verifikasi tanda tangan seseorang. Hasil pengujian tanda tangan menunjukan bahwa aplikasi yang dibangun mampu mengenali tanda tangan yang diujikan dengan ketepatan $84 \%$ (Widiastuti, dkk, 2014).

Meskipun telah menerapkan JST dengan kompleksitas yang tinggi, masih diperoleh tingkat kesalahan yang masih cukup tinggi, yakni $16 \%$. Untuk itu, diharapkan penelitian yang diajukan ini mampu meningkatkan keakuratan serta menurunkan kompleksitas dalam proses verifikasi tanda tangan.

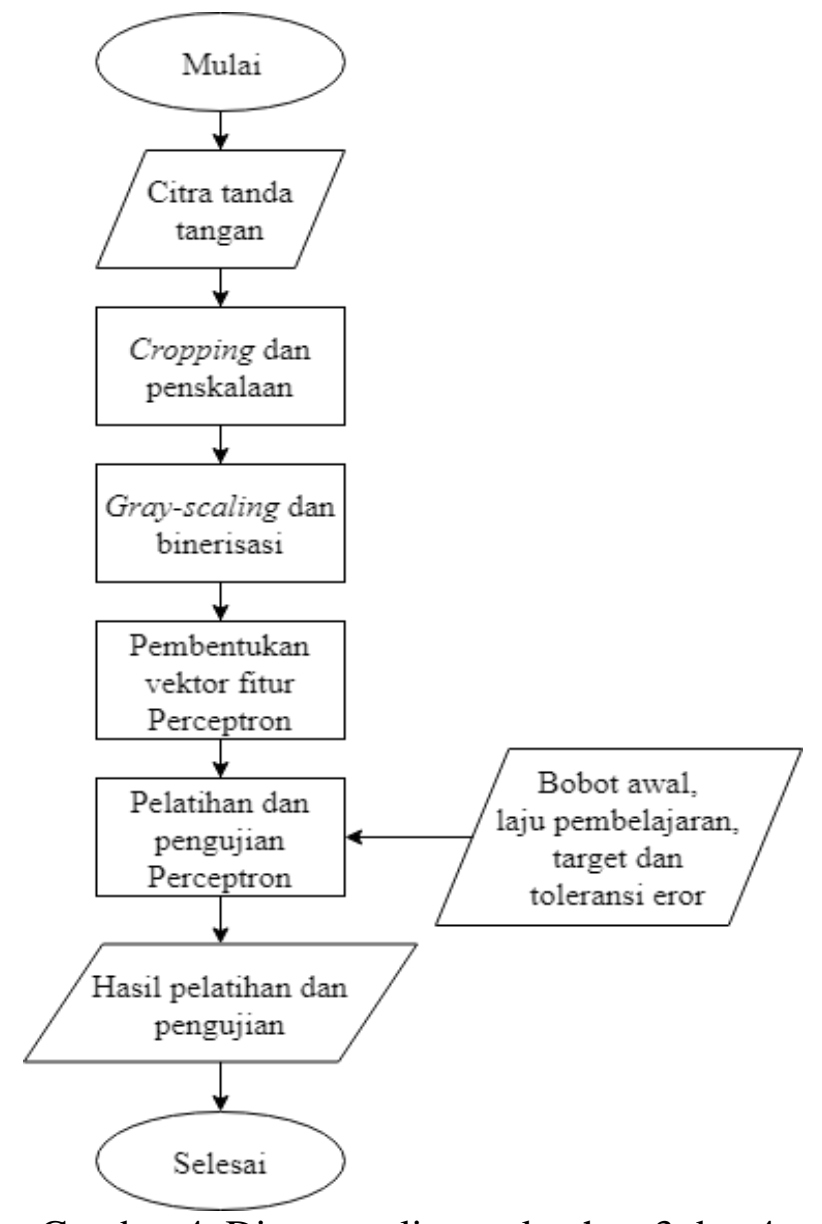

Gambar 4. Diagram alir untuk tahap 3 dan 4. 


\section{B. Tahap 2. Pengambilan Data Penelitian}

Pembuatan sampel tanda tangan dilakukan dengan cara mengambil tanda tangan dari setiap responden. Terdapat dua responden pada penelitian ini, dimana masing - masing membubuhkan 21 tanda tangan, sehingga didapatkan 42 buah sampel tanda tangan. Dengan rincin sebagai berikut :

1) Untuk data pelatihan, digunakan sebanyak 14 citra yang mewakili tanda tangan dari kedua responden. Lebih lanjut, data pelatihan meliputi 8 citra tanda tangan asli (masing - masing 4 citra dari setiap responden) dan 6 citra tanda tangan palsu (masing - masing 3 citra dari setiap responden).

2) Untuk data pengujian, digunakan sebanyak 28 citra yang mewakili tanda tangan dari kedua responden. Lebih lanjut, data pengujian meliputi 20 citra tanda tangan asli (masing - masing 10 citra dari setiap responden) dan 8 citra tanda tangan palsu (masing - masing 4 citra dari setiap responden).

Setiap sampel yang dihasilkan akan dilakukan proses pemindaian untuk memperoleh citra digital yang dapat diolah menggunakan komputer. Citra digital tanda tangan tersebut nantinya akan menjadi masukan dari sistem yang dibangun sehingga akan menghasilkan keluaran verifikasi tanda tangan dari responden orang yang berbeda beda.

\section{Tahap 3. Pengolahan Citra}

Pengolahan citra dilakukan untuk menghasilkan fitur masukan yang dibutuhkan pada proses verifikasi. Ukuran tiap citra diseragamkan menjadi ukuran piksel yang sama dengan proses cropping manual dan penskalaan. Cropping manual yang dimaksud disini dilakukan sesuai dengan kebutuhan menurut peneliti. Selanjutnya, dilakukan proses gray-scalling, yaitu mengubah citra warna menjadi citra berderajat keabuan yang nantinya citra tersebut akan diubah menjadi citra biner. Tahap pengolahan citra ditunjukkan oleh bagian atas diagram alir pada gambar 4 .

Cropping dan penskalaan dilakukan secara manual untuk menyeragamkan ukuran setiap citra. Setelah itu, setiap citra yang merupakan citra warna tersebut diubah menjadi citra berderajat keabuan atau grayscale. Tujuan dari pengubahan tersebut adalah untuk menurunkan beban komputasi pada proses selanjutnya. Selanjutnya dilakukan proses binerisasi untuk mengubah citra berderajat keabuan menjadi citra biner, yang terdiri atas piksel 0 untuk hitam dan 1 untuk putih menggunakan nilai ambang tertentu.

\section{Tahap 4. Verifikasi Citra dengan Perceptron}

Hasil proses binerisasi digunakan sebagai masukan pada proses pelatihan perceptron. Sebelumnya, dilakukan tahap pembagian data untuk keperluan pelatihan dan pengujian. Pembagian data menjadi data untuk pelatihan dan pengujian dilakukan menggunakan metode random sampling, dengan rasio jumlah data pelatihan dan pengujian adalah $1: 2$, yaitu 14 data pelatihan dan 28 data pengujian. Pada proses pembentukan vektor fitur, yakni pengubahan ukuran setiap citra biner yang semula berupa matriks berukuran $\mathrm{L} \times \mathrm{T}$ menjadi vektor baris berukuran $1 \times(\mathrm{L} \times \mathrm{T})$. Apabila terdapat $\mathrm{N}$ buah citra pelatihan, maka matriks fitur pelatihan akan berukuran $\mathrm{N} \times(\mathrm{L} \times \mathrm{T})$.

Proses pelatihan dilakukan dengan matriks fitur pelatihan sebagai masukannya. Pada proses pelatihan, ditentukan nilai bobot optimal untuk memetakan citra pelatihan ke identitas dari pemilik tanda tangan tersebut. Bobot optimal yang didapatkan akan digunakan pada proses verifikasi, yakni memetakan citra pelatihan maupun pengujian ke identitas responden tertentu. Pada akhirnya, proses verifikasi dinyatakan berhasil apabila identitas yang dihasilkan dari proses tersebut cocok atau sesuai dengan identitas dari pemilik citra tanda tangan yang sesungguhnya. Pada proses 
pelatihan digunakan target 1 dan -1 , dimana 1 menyatakan citra tanda tangan asli dan -1 menyatakan citra tanda tangan palsu.

\section{E. Tahap 5. Pengukuran Performa Metode}

Data fitur yang didapatkan dari pengolahan citra digunakan sebagai masukan untuk perceptron. Analisis hasil verifikasi perceptron terhadap target verifikasi dilakukan untuk mengetahui tingkat akurasi sistem verifikasi citra tanda tangan. Jumlah hasil verifikasi yang sesuai obyek tanda tangan dinyatakan dengan $\Sigma$ sesuai dan jumlah sampel per kategori dinyatakan dengan $n$. Dari hasil tersebut, tingkat akurasi sistem dapat dihitung dengan persamaan berikut :

Akurasi $=\frac{\sum \text { sesuai }}{n} \times 100 \%$

\section{HASIL DAN PEMBAHASAN \\ 4.1. Pengolahan Citra}

Terdapat 42 citra yang diolah pada penelitian ini. Citra - citra tersebut terdiri dari 28 citra dengan tanda tangan asli dan 14 citra dengan tanda tangan palsu. Pada citra citra tersebut dilakukan serangkaian teknik pengolahan citra guna menghasilkan fitur pola tanda tangan dari setiap responden yang mudah dibedakan.

\section{Cropping}

Cropping atau pemotongan citra merupakan proses pengolahan citra guna menghasilkan ukuran citra yang lebih kecil dari ukuran sebelumnya, dengan mengurangi luasan citra yang tidak dibutuhkan. Bagian citra yang dibutuhkan pada penelitian ini ialah bagian citra yang memuat tanda tangan. Sehingga luasan citra yang tidak memuat tanda tangan dapat dibuang dengan menggunakan yaitu teknik pemotongan / cropping ini. Contoh salah satu citra original tanda tangan dari dua responden yang digunakan ditunjukkan oleh gambar 5 .

Dari citra - citra original pada gambar 5 tersebut, dilakukan proses pemotongan untuk memfokuskan citra tanda tangan yang akan diproses pada tahap - tahap selanjutnya. Proses tersebut dilakukan sebab terlalu banyaknya luasan citra yang tidak memuat tanda tangan pada citra diatas. Hasil proses pemotongan pada pengolahan citra ini dapat dilihat pada gambar 6.

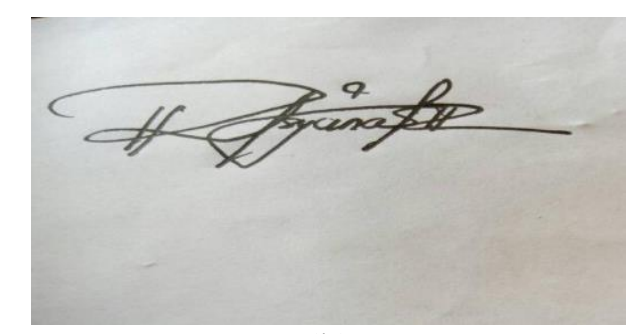

(b)

(a)

Gambar 5. Citra Tanda Tangan Original dari

(a) Responden Pertama dan (b) Responden Kedua.

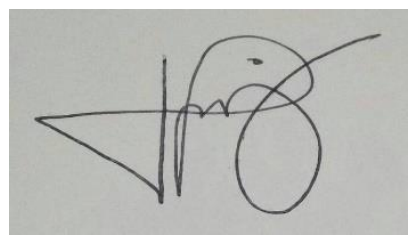

(a)

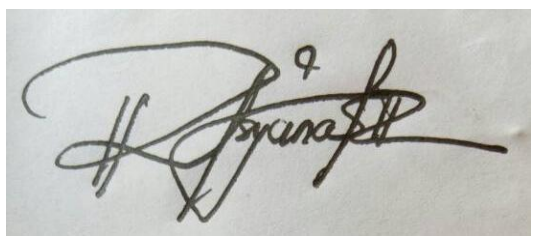

(b)

Gambar 6. Citra Tanda Tangan Hasil Proses Pemotongan dari (a) responden pertama dan (b) responden kedua 


\section{Penskalaan}

Setiap citra juga mempunyai ukuran yang berbeda - beda. Ukuran citra bisa digambarkan dengan menggunakan kata sifat dan satuan ukuran citra. Kata sifat yang menggambarkan ukuran citra, misalnya citra besar, citra kecil, citra sedang, dan lain sebagainya. Sedangkan ukuran citra secara obyektif digambarkan dengan satuan ukuran citra misalnya meter, piksel, inch, dan lain sebagainya. Pada penelitian ini, semua citra yang digunakan mempunyai ukuran citra yang berbeda - beda. Agar dapat diolah ke dalam proses selanjutnya, citra - citra tersebut diseragamkan ukurannya. Ukuran citra yang digunakan pada penelitian ini ialah $150 \times 200$ piksel. Sehingga keluaran dari proses ini ialah semua citra yang digunakan akan berukuran $150 \times 200$ piksel.

Gambar 7 menunjukkan salah satu contoh citra sebelum dan sesudah dilakukan tahap penyeragaman ukuran citra, dimana citra sebelum dilakukannya proses ini merupakan citra hasil proses pemotongan.

\section{Grayscalling}

Grayscalling ialah salah satu proses pada pengolahan citra dimana pada hasilnya akan diperoleh citra dengan setiap pikselnya hanya berisikan informasi intensitas warna antara putih dan hitam. Tahapan ini wajib dilakukan sebab citra hasil penskalaan masih berupa citra warna tiga kanal (RGB) yang pada dasarnya dapat diwakili dengan citra satu kanal (grayscale) saja. Hasil dari tahapan ini dibutuhkan pada proses proses binerisasi, yang akan dilaknakan setelah tahapan gray-scalling.

Gambar 8 menunjukkan contoh citra sebelum dan sesudah dilakukan tahap grayscalling ukuran citra, dimana citra sebelum dilakukannya proses ini merupakan citra hasil proses penyeragaman ukuran.

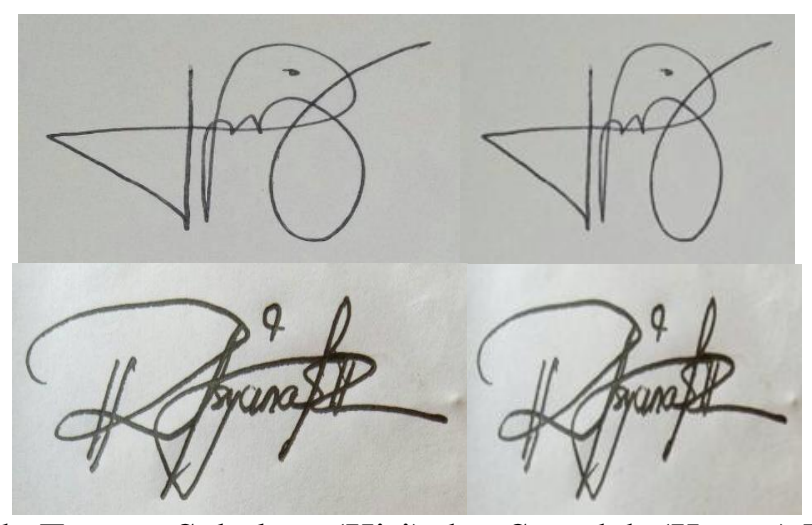

Gambar 7. Citra Tanda Tangan Sebelum (Kiri) dan Sesudah (Kanan) Proses Penyeragaman Ukuran dari Sampel Pertama (Atas) dan Sampel Kedua (Bawah).

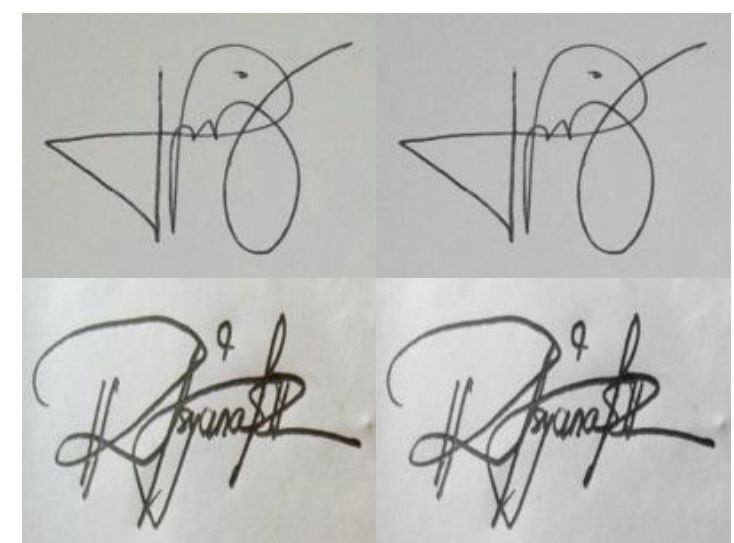

Gambar 8. Citra Tanda Tangan Sebelum (Kiri) dan Sesudah (Kanan) Proses Gray-Scalling dari Sampel Pertama (Atas) dan Sampel Kedua (Bawah). 


\section{Binerisasi}

Tahapan terakhir sebelum dilakukannya proses verifikasi citra tanda tangan dengan menggunakan perceptron ialah binerisasi. Citra masukan perceptron membutuhkan citra dengan intensitas hanya dua macam warna, yaitu hitam dan putih. Untuk mendapatkan citra dengan karakteristik tersebut, dibutuhkan suatau metode pengolahan citra, yaitu binerisasi. Telah diketahui bahwa dari proses sebelumnya, yaitu gray-scalling, telah diperoleh citra dengan intensitas antara hitam dan putih.

Sehingga untuk proses binerisasi akan ditetapkan intensitas menjadi hitam dan putih. Gambar 9 menunjukkan salah satu contoh citra sebelum (hasil gray-scaling) dan sesudah dilakukan tahap binerisasi. Dari hasil citra biner atau hitam putih, diperoleh nilai - nilai intensitas dari matriks citra yang bernilai satu atau nol. Nilai - nilai tersebut akan menjadi fitur masukan dari metode perceptron. Matriks - matriks citra tersebut berukuran $1 \times(150 \times 200)$ yang berisi kumpulan nilai-nilai piksel pada masing masing citra biner.

\section{Pelatihan Perceptron}

Langkah terakhir adalah melakukan proses verifikasi dengan perceptron. Sebelum citra - citra tersebut diverifikasi dengan perceptron, dilakukan pelatihan citra dengan menggunakan metode tersebut terlebih dahulu. Seperti yang telah disebutkan sebelumnya, citra yang digunakan pada penelitian ini berasal dari dua responden. Sehingga, tahap pelatihan perceptron pada masing - masing responden dilakukan secara terpisah. Proses pelatihan menggunakan citra dari kelompok pelatihan. Hasil verifikasi data pelatihan responden pertama disajikan pada tabel 1 .

Dari tabel 1, terlihat bahwa untuk data responden pertama diperoleh kecocokan $100 \%$. Hal tersebut ditunjukkan dari kesamaan keluaran dari nilai target dan hasil pelatihan. Dengan kata lain, Perceptron dapat melatih pengenalan tanda tangan dengan baik. Nilai 1 menunjukkan bahwa citra tersebut merupakan citra dengan tanda tangan asli dari responden pertama dan nilai -1 menunjukkan bahwa citra tersebut merupakan citra dengan tanda tangan palsu yang bukan merupakan tanda tangan responden pertama. Terdapat 4 citra tanda tangan asli dari responden pertama dan 3 citra tanda tangan palsu yang bukan merupakan tanda tangan dari responden pertama.
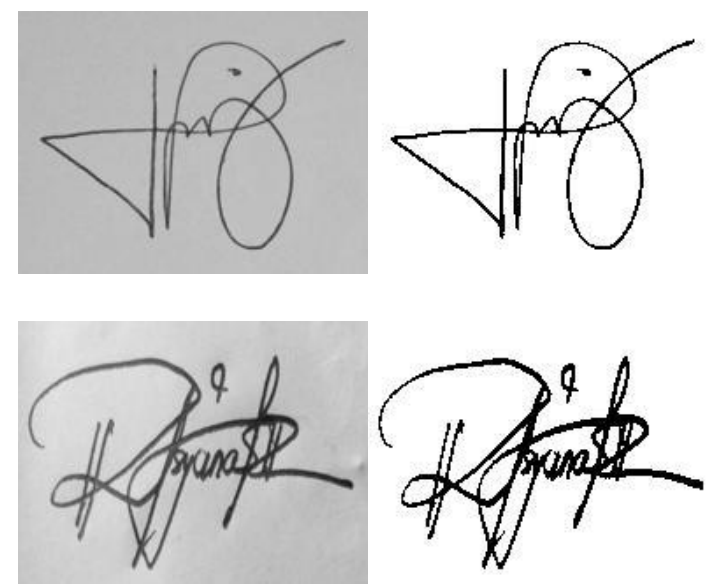

Gambar 9. Citra Tanda Tangan Sebelum (Kiri) dan Sesudah (Kanan) Proses Binerisasi dari Sampel Pertama (Atas) dan Sampel Kedua (Bawah). 
Tabel 1. Hasil Verifikasi Data Pelatihan Responden Pertama

\begin{tabular}{|c|c|c|c|}
\hline No & Citra & Target & Hasil Pelatihan \\
\hline 1 & & 1 & 1 \\
\hline 2 & & 1 & 1 \\
\hline$\ldots$ & $\ldots$ & ... & $\ldots$ \\
\hline 7 & & -1 & -1 \\
\hline
\end{tabular}

Tabel 2. Hasil Verifikasi Data Pelatihan Responden Kedua

\begin{tabular}{|c|c|c|c|}
\hline No & Citra & Target & Hasil Pelatihan \\
\hline 1 & & 1 & 1 \\
\hline 2 & & 1 & 1 \\
\hline$\cdots$ & $\ldots$ & ... & ... \\
\hline 7 & & -1 & -1 \\
\hline
\end{tabular}


Tabel 3. Hasil Verifikasi Data Pengujian Responden Pertama

\begin{tabular}{|c|c|c|c|c|}
\hline No & Citra & Target & Hasil & Ket \\
\hline 1 & & 1 & 1 & Asli \\
\hline 2 & & -1 & -1 & Palsu \\
\hline$\ldots$ & $\cdots$ & $\ldots$ & $\ldots$ & $\ldots$ \\
\hline 14 & & 1 & 1 & Asli \\
\hline
\end{tabular}

Tabel 4. Hasil Verifikasi Data Pengujian Responden Kedua

\begin{tabular}{|c|c|c|c|c|}
\hline No & Citra & Target & Hasil & Ket \\
\hline 1 & & 1 & 1 & Asli \\
\hline 2 & & -1 & -1 & Palsu \\
\hline$\ldots$ & $\cdots$ & $\ldots$ & $\ldots$ & $\ldots$ \\
\hline 14 & & 1 & 1 & Asli \\
\hline
\end{tabular}


Proses pelatihan juga dilakukan pada data pelatihan responden kedua. Hasil pelatihan pada citra tanda tangan responden kedua ditampilkan pada tabel 2. Pada tabel 2, terlihat bahwa untuk kelas responden kedua diperoleh kecocokan 100\%. Hal tersebut ditunjukkan dari kesamaan keluaran dari nilai target dan hasil pelatihan. Dengan kata lain, perceptron dapat melatih pengenalan tanda tangan dengan baik. Nilai 1 menunjukkan bahwa citra tersebut merupakan citra tanda tangan asli dari responden kedua dan nilai -1 menunjukkan bahwa citra tersebut merupakan citra tanda tangan palsu yang bukan merupakan tanda tangan responden kedua. Terdapat 4 citra tanda tangan asli dari responden kedua dan 3 citra tanda tangan palsu yang bukan merupakan tanda tangan dari responden kedua.

Dari tabel 1 dan 2, dinyatakan bahwa sistem pelatihan telah berjalan dengan baik dengan hasil, yaitu responden pertama diperoleh akurasi $100 \%$ dan responden kedua diperoleh akurasi 100\%. Untuk itu, sistem telah siap untuk digunakan dalam pengujian verifikasi tanda tangan.

\section{Pengujian Citra Tanda Tangan}

Terdapat 14 tanda tangan dari kelas responden pertama yang telah dilakukan pengujian. Dari proses ini diperoleh bahwa sebanyak 10 citra tanda tangan asli dari responden pertama dan 4 citra tanda tangan palsu bukan dari responden pertama. Keempat belas citra tersebut setelah dilakukan pengujian diperoleh hasil bahwa ada satu citra yang tidak sama antara keluaran target dengan hasil pengujian. Hal tersebut sesuai dengan tabel 3 Untuk itu, diperoleh $13 / 14 \times 100 \%=92,85 \%$.

Untuk responden kedua, hasil pengujian ditampilkan pada tabel 4. Terlihat pada tabel 4 bahwa terdapat 14 citra tanda tangan dari kelas responden kedua yang telah dilakukan pengujian. Dari proses ini diperoleh bahwa sebanyak 10 citra tanda tangan asli dari responden kedua dan 4 citra tanda tangan palsu bukan dari responden kedua. Keempat belas citra tersebut setelah dilakukan pengujian diperoleh hasil bahwa ada satu citra yang tidak sama antara keluaran target dengan hasil pengujian. Untuk itu, akurasi hasil pengujian dari responden kedua yaitu akurasi $=13 / 14 \times 100 \%=92,85 \%$.

Dari kedua responden diatas, diperoleh rerata hasil pelatihan sebesar $100 \%$ dengan rincian $100 \%$ dari responden pertama dan $100 \%$ dari responden kedua. Akurasi untuk hasil pengujian sebesar $92,85 \%$ dengan rincian $92,85 \%$ dari responden pertama dan $92,85 \%$ dari responden kedua. Gambar 10 merupakan tampilan dari aplikasi ini.

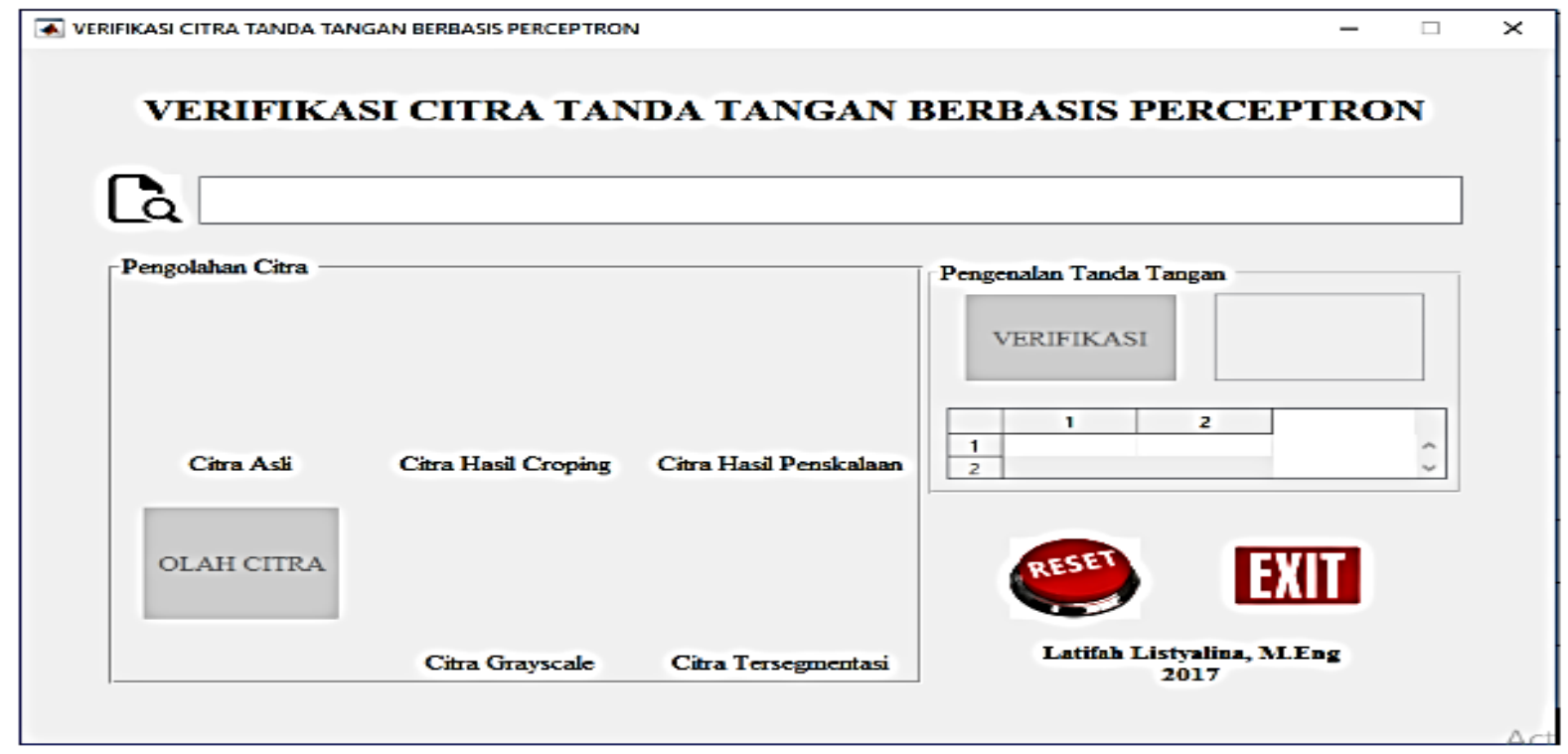

Gambar 10. Tampilan Aplikasi Verifikasi Tanda Tangan. 


\section{KESIMPULAN}

Pada penelitian ini verifikasi tanda tangan berbasis perceptron telah berhasil dibuat dimana ada beberapa langkah yang telah dilakukan, yaitu proses pemotongan, penyeragaman ukuran, grayscalling, biner, dan verifikasi dengan perceptron. Akurasi sistem verifikasi citra tanda tangan terdiri dari dua hal, yaitu akurasi pelatihan $100 \%$ dan akurasi pengujian $92,85 \%$.

\section{Ucapan Terima Kasih}

Penulis mengucapkan terima kasih kepada Universitas Respati Yogyakarta yang telah memberi dukungan finansial terhadap penelitian ini. Terima kasih kami sampaikan pula Pusat Penelitian dan Pengabdian kepada Masyarakat dan segenap rekan sejawat di Universitas Respati Yogyakarta yang telah membantu dalam proses penyelesaian penelitian ini.

\section{DAFTAR PUSTAKA}

Abbas, R, “A Prototype System for Off-Line Signature Verification Using Multilayered Feedforward Neural,”. RMIT., 1994.

Andrizal, dkk, "Pendeteksi dan verifikasi tanda tangan menggunakan metode image domain spasial," Jur. Sist. Komput. Fak. Teknol. Inf. Univ. Andalas Padang., 2014.

Gonzales, dkk, Digital image processing, 2nd ed. New Jersey: Prentice Hall., 2008.

Hidayatno, dkk, "Identifikasi Tanda-Tangan Menggunakan Jaringan Saraf Tiruan Perambatan-Balik (Backpropagation) Achmad," Jur. Tek. Elektro Fak. Tek. Univ. Diponegoro, pp. 100-106., 2008.

Kusumadewi, Membangun Jaringan Syaraf Tiruan Menggunakan Matlab \& Excel Link. Yogyakarta: Graha Ilmu., 2004.
Listyalina, Latifah, "Identifikasi Otomatis Anemia pada Citra Sel Darah Merah Berbasis Komputer," vol. 11, no. 3., 2017.

Musyaffa, F.A, "Signature Recognition using VFI5 Algorithm and Wavelet Preprocess.," Institut Pertanian Bogor., 2009.

Putra, D, Pengolahan Citra Digital. Yogyakarta: Penerbit Andi., 2010.

Putra, dkk, " Pengenalan Tanda Tangan Dengan Menggunakan Probabilistic Neural Network," Fak. Tek. Inform. Univ. Telkom., 2013.

Widiastuti, dkk. "Jaringan Saraf Tiruan Backpropagation Untuk Aplikasi Pengenalan Tanda Tangan," Progr. Stud. Tek. Inform. Fak. Teknol. Ind. Univ. Pembang. "Veteran" Yogyakarta, pp. 69-76., 2014. 